Review

\title{
Eco-Dimensionality as a Religious Foundation for Sustainability
}

\author{
Susan Power Bratton \\ Department of Environmental Science, P.O. Box 97266, Baylor University, Waco, TX 76798, USA; \\ Susan_Bratton@Baylor.edu; Tel.: +1-254-710-6566
}

Received: 20 February 2018; Accepted: 27 March 2018; Published: 30 March 2018

\begin{abstract}
Academics have critiqued the Abrahamic faiths, particularly Christianity, as inadequate to respond to today's environmental dilemmas due to abstract theological qualities like the concept of a unified or transcendent God. Christianity and Islam are the earth's most populous religions, however, and they are growing in the global south. A literature review finds that both indigenous and world religions develop strategies for environmental sustainability. Examples include: Amazonian fisheries, Islamic gardens, monastic forest management, Baptist LEED certified buildings, and Christian agrarian stewardship. These cases share a characteristic termed eco-dimensionality, defined as the integrative expression of environmental values, caretaking norms and sustainable practices in all aspects of religion, that recognizes and specifically adapts to keystone environmental processes and ecosystemic or geo-physical diversity. Religious eco-dimensionality incorporates: inventorying biota and ecosystems, recognizing environmental spatial and temporal dynamics at multiple scales, understanding communitarian and anti-communitarian human behaviors, structuring social networks, adopting sustainable technologies, and developing an integrative repertoire of religious symbols, aesthetic endeavors and ceremonies. Eco-dimensionality can evolve to address new issues. Negatively stereotyping faith traditions can inhibit constructive conversations concerning environmental issues and development of religious symbols and practices enhancing eco-dimensionality.
\end{abstract}

Keywords: environment; religion; ritual; ecology; fisheries; gardens; LEED buildings; ecotheology; Christianity; Islam

\section{Introduction}

One of the persistent barriers to seeking a productive interface between the world's religions and environmental problem solving is the inclination to distinguish 'environmentally good' religions from 'environmentally bad' or ineffective religions. Both popular and scholarly interpretation generalizes the environmental values of such diverse faiths as Christianity and Hinduism. On the academic side, universities reward scholars for innovation, which promotes critique of dominant or mainstream religious forms. Both environmental advocates and academics propose new eco-friendly alternatives-often without any in-depth conversations with adherents of the "bad" or "old" religion. The new or alternative religious philosophies, like the Dark Green Religion proposed by Bron Taylor, are eco-centric and focused on contemporary concepts of sustainability [1]. These endeavors open dialog, and encourage environmentally conscientious behaviors. The problem is Christianity is the most populous religion on the planet, with Islam as an increasingly close second. According to the Pew Forum on Religion and Public Life, Islam is the fastest growing religion, and the earth's population is becoming more religious not less. By 2050 , about $87 \%$ of planet's inhabitants will have a religious affiliation. Only 5 to $6 \%$ will remain in indigenous or traditional religions, about the same as currently - the majority will adhere to a world religion like Islam or Buddhism, with the major 
branches and sects of the Abrahamic faiths (Judaism, Christianity, Islam) in the lead [2]. Indigenous and regional religions are those encompassing one language or ethnic group or a limited geographic region. They overlap with the concept of traditional religions-those little modified by industrialization or modernity. In the face of globalization, the world religions will continue as advantaged due to their outreach, cadres of religious professionals, organizational leadership, emphasis on education, and ability to adapt to both urban and rural environments. An additional observation is that new or alternative religions originating in the US or Europe appeal differentially to the upper socio-economic strata or to the professional classes, and their practice is often individualized [3]. Pentecostalism, in contrast, has spread widely among less economically advantaged populations in the global south, and has a basis in participatory worship services and encouraging self-empowerment via community support [4].

Summarily putting the "eco" first in religion has the disadvantage of ignoring all the other roles religions play in people's daily lives. Religions have diverse functions, such as recognizing and ordering life transitions, discouraging behaviors damaging the interests of relatives and neighbors, and encouraging fidelity to a clan or social group. Some religious activities, like seasonal agricultural festivals, present obvious environmental linkages, while others, like praying for the dead, center on human emotional needs. Historically, religions have often failed to adequately address major environmental failures, such as the hunting species to extinction, removing montane forest cover or modifying dryland hydrology. Overhunting, overgrazing, soil erosion and famine are ancient concerns. Yet, in the current era of urbanization and globalization, the scale of both the problems and failures has expanded. In response to environmental challenges of this magnitude, Christian denominations, for example, have been inconsistent in their effort and commitment-varying from activist and inventive concerning sustainability, to combatting international agreements for mitigating climate change. The process of "greening" world religions, however, remains critically important to attaining sustainable environmental strategies, and must systematically consider and accommodate religion's other functions.

The purpose of this paper is to first examine why some religious approaches are more effective at encouraging environmental sustainability, and to summarize this quality as eco-dimensionality. Eco-dimensionality is the integrative expression of environmental values, caretaking norms and sustainable practices in all aspects of religion, including symbolism, myth, art, ritual, and ethics, that recognizes and specifically adapts to keystone environmental processes and ecosystemic or geo-physical diversity. The analysis then reviews two well documented cases of indigenous religions contributing to fisheries sustainability. The purpose is to identify religious features of these strategies that might be shared among religions more universally. The next section briefly reviews selected environmental critiques aimed at Christianity, and consequentially at Islam and Judaism, including anthropocentrism, human exceptionalism, and the centrality of a transcendent deity. I will then argue the relative degree of eco-dimensionality and the level of community networking are better means for evaluating the viability of a religious approach to sustainable practices than abstract theological qualities. Not bound to western theological traditions, the concept of eco-dimensionality can describe and compare environmental strategies of religions from diverse geographies and cultural linages. While eco-theology as process remains an important means of communicating and strategizing within a faith or denomination, eco-dimensionality offers a bridge for conversations with scientists and policy makers due to its refined interface with critical environmental variables.

\section{Materials and Methods}

In reading the contemporary literature, cases of constructive approaches to environmental problem solving and sustainable life styles emerge across the spectrum of religious traditions. Jewish agriculturalists recycle water, Hindus protect forest sanctuaries and Muslims celebrate an iftar favoring locally grown produce to break the daily fasts of Ramadan [5]. Anthropological and comparative religious studies point to the effectiveness of indigenous or regional religions in 
constraining overharvest of local consumptive resources and in maintaining eco-system services. This leads to the question: which aspects of religion serve as the keystones of sustainability? As a review and a synthesis of concepts, this article summarizes four selected cases of religiously driven sustainable practices drawn from the environmental history or anthropological literature, and two cases from contemporary religious organizations reporting their sustainability programs on their web sites. The review also draws on environmental history to briefly address the effectiveness of sacred groves at the watershed scale and the benefits of Christian agrarianism. The cases do not represent parallel economies. Instead, they allow a comparison of positive approaches to sustainability with a high degree of religious integration across a range of cultural traditions and organizational scales.

\section{Results}

\subsection{Indigenous Religions Generate Eco-Dimensionality to Sustain Fisheries}

Beginning with indigenous or regional religions, comparing two well-known examples from fisheries management will provide insights. Prior to the arrival of European-heritage settlers, the tribes of northern-eastern Pacific Rim had been harvesting salmon for many centuries. Their religious approach to salmon is multi-faceted, and not expressed in creation myths alone. Ethical stories, settlement-wide ceremonies, religious taboos and prohibitions, religious art, and family fishing territories operate together to enhance the value of living salmon. This integrative religious framework acts not just to generate respect for salmon as a general class of organism but to conserve the specific breeding streams, runs, and genetic stocks. Environmental historian Joseph Taylor III has reasoned the widespread practice of the First Fish Ceremony, which temporarily halts fishing after the first fish is caught, allowed escapement at the beginning of each run, assuring some breeding fish reach each stream in a watershed [6]. Unlike a closed fishing season when no fishing is permitted and everyone waits impatiently on the river bank, the First Fish Ceremony serves as a participatory festival, building community solidarity.

Interreligious environmental comparisons of religious myths often focus on creation narratives, but other forms of religious literature and art can convey more detailed instruction. On the north Pacific Rim, humorous Coyote tales deliver lessons about correct social behavior. The Klamath Tribe's version of "Coyote and the Salmon" depicts the sly trickster as opening a dam built by Skookums (bad people or monsters) that was restricting salmon from reaching their breeding sites, and preventing the Klamath upstream from harvesting salmon. Without explicitly banning overharvest, the tale is a wry commentary on the damages of greed and inappropriate technology [7]. North Pacific legends also relate the adventures of salmon boy who violated tribal norms for the respectful treatment of salmon and preventing waste of a critical food. The fish carried him out to sea, to live in the salmon realm, and the boy ultimately returned to his parents in the form of a salmon [8]. An advantage of these tales is they are easily remembered, and shared with youth. Narratives of shape-shifting and animals with their own tribes equate the interests of the fish with human interests, and emphasize respect and co-existence. Taylor concludes a combination of "aboriginal spiritual beliefs, ritual expression, social sanctions and territorial claims effectively moderated salmon harvests" [6]. It is important to recognize that even these refined religious systems with their recognition of multiple temporal, spatial and biotic factors relative to salmon populations still permit continuing human impacts. In allowing greater escapement at the beginning of a run, the First Fish Ceremony awards the early arrivals a survival advantage which may subtly influence a local population's genetics and breeding patterns. The salmon in turn must accommodate long term climatic trends, and the prevalence of other predators in optimizing the timing of their runs.

If some cultures dependent on harvest of consumptive resources emphasize sacred time, others emphasize sacred space. A common religious strategy is to designate keystone resources. Like old growth forest groves or upper watershed springs, as sacred terrains completely off-limits for harvest or only available during defined times. The Tukano people of the upper Rio Negro, Brazil, 
are dependent on root crops from their garden patches and freshwater fish. Aside from closing fishing during prescribed seasons, they fish less than $40 \%$ of the river margin and have designated riparian refuges for aquatic life. The Tukano establish the houses for fish totems within the flood plains-thereby sacralizing the critical spawning areas and established safe reproductive zones for the aracu (Leporinus species) on which they depend. In Tukano belief, the forests belong to the fish. According to pan-Tukano myths, a great ancestral anaconda-fish became the progenitor of each local clan. The weapon-bearing clans defend their territories from other clans and tribes, based on the concept of ancestral precedence [9].

The religions of the north Pacific Rim and the upper Rio Negro share repeated references to fish. They imbed and cross-reference conservation strategies in myth, ritual, and religiously mediated regulation. The First Fish Ceremony is a specific temporal adaptation to the multi-phase life cycles of diverse salmon species, while the closed breeding grounds are more appropriate to species laying eggs in flooded riparian forests. The religions utilize anthropomorphic imagery to identify fish as human ancestors or to credit non-human creatures with societies or virtues of their own. Religion thus reduces the "thingness" of fish, and raises their status relative to humans. Humans can treat all material, living or not, as mere stuff to manipulate or consume. Among the First Nations of the Pacific Rim, in contrast, salmon are no longer mere objects for ownership, abuse or disposal at human whim. Moving beyond awarding fish, forests and coyotes intrinsic worth, religions credit them with supernatural powers, ethical insights, and primordial authority. Religion imparts a deep sense value and greater personal identification with selected species and ecosystem processes. Sacralization underpins both continuing recognition of essential ecological processes, like fish spawning. Operating as an interactive whole, religion retains and conveys indigenous spatial-temporal knowledge concerning fish spawning patterns, and constrains human inclinations towards anti-social excess in the forms of greed and waste. Rituals and shared stories foster community cooperation. Taboos backed by sanctions reduce motivation for individuals to act independently or selfishly. These religions are highly eco-spatial, or considering time and biodiversity as key dimensions, express complex and precise eco-dimensionality. Disruptions via colonialism, warfare, population migration or exogenous environmental factors like repeated severe droughts can constrain or undermine religious eco-dimensionality. Early US state attempts at managing salmon, for example, dismantled the refined geography of Native American harvest, and thereby eliminating accountability for maintaining breeding populations at the small watershed scale. In building "industrial" salmon hatcheries, government agencies ignored the genetic adaptation of the runs to very specific seasonal and stream conditions [6].

\subsection{Critiques Directed at the Abrahamic Faiths in Historic Context}

As the environmental movement developed momentum in the 1960s, western soul searching began to look for possible cultural roots for the accumulating damages caused by industrialization. The modern science and technology driving industrialization had initially emerged in Euro-American contexts where Christian theology reigned in academic religion. These associations led to historic examinations of Christian beliefs concerning the origins, meaning and ethical valuation of living creatures and the earth. In 2017, Todd LeVasseur and Anna Peterson [10] published an edited volume incorporating diverse scholarly perspectives on the best known of these critiques, Lynn White Jr.'s "Historic roots of our ecological crisis," which appeared in Science in 1967 [11]. White pointed to the transcendence of the Christian triune deity, where God is exterior to and over Creation, as reducing Christian fear of nature and willingness to harvest and manipulate at will. According to White, the spiritual presence in individual natural objects in the animist cosmos generated greater respect and inhibited environmental abuse. He distinguished "pagan" recognition of spirits resident in trees and other natural objects as an example of religious protection. White identified Christianity as the most anthropocentric religion, and drew attention to religious human exceptionalism-the idea that people are separate from and superior to nature. God created the earth specifically for human residence and all other creatures and natural materials should serve humanity's needs. In response, late 20th century 
environmentalism searched for a biocentric and ecocentric ethics to replace self-centered, materialistic Christianity—and de facto monotheistic Judaism and Islam.

White's accusations of Christian anthropocentrism and human exceptionalism are logically problematic as religions in general attribute human characteristics to deities, and many indigenous traditions incorporate anthropomorphic portrayals of other species or natural phenomena like the primordial anaconda-fish spawning the Tukano clans. Further, in pursuing sustainability, providing for human needs remains a core metric of success. White never defined anthropocentrism in a way that would allow measurement of its potential negative environmental impacts or provide a comparison among religious systems. The ancient Greeks, for example, placed sculptures of gods and goddesses in human form wearing clothes and armor in their temples or across their friezes, and believed that heroes could be the hybrid progeny of their pantheon. Greek deities participated in war and in human trades like weaving. It remains to be seen why the unseen ancient Hebrew unified god as a behavioral model is more anthropocentric than Zeus or Athena. The simple dichotomy that religions are either human or nature centered obscure the nuanced connections between humans, the environment and the supernatural or cosmological that characterize religious systems contributing to sustainability.

The unexamined acceptance of one major form of religion as nature-friendly and another form as perpetually inadequate discourages comparative examination of religious failure to respond to excessive resource exploitation, soil erosion, water contamination, species extinction and climate change-all of which were ancient as well as current dilemmas. Although many scholars have interpreted White as intending to elicit a more ethically responsible Christian response to the growing environmental impacts of industrialization, White romanticized pre-Christian European religions and based some of his conclusions on casual historiography. His argument that "pagan" belief in spirits resident in trees the concept of genius loci protected forests, for example, ignored Greco-Roman degradation of woodlands in the Mediterranean region, which archeologists and historians had begun to document prior to the 1960s [12]. Not surprisingly for a seminary-trained Presbyterian, White pointed to Latin Catholicism as a culprit in western environmental indifference, and then touted pre-Christian sacred groves [11]. The groves attached to Greek and Roman temples were originally in forested matrices, but as the shrines aged, logging and grazing left the groves as isolated woodlots in an open landscape [13]. Further, diverse Christian traditions have protected individual sacred trees or forests on holy ground. Irish Catholics still tie strips of cloth and ex-votive offerings on oaks and other woody plants at holy wells and other pilgrimage foci, like ruined medieval churches associated with Celtic saints [14]. Christian monasteries in Ethiopia that protect trees and wildlife in their enclosures have found themselves becoming isolated islands of biodiversity in a sea of desertification as local farmers overharvest and overgraze the woodlands around the monasteries. Writing holy trees off as a "pagan retentions" and thereby not genuinely Christian, reflects a Reformation bias against sacralizing natural objects, such as oaks and springs, that still crops up in today's religious scholarship [15]. White's arguments also ignore the continuing roles of trees in Christian ritual and ethos. Unlike their Tukano analogs, the Roman polytheist and Ethiopian Christian religious reserves have not been effective in maintaining forest cover at the watershed scale. The question of why is beyond the scope of this paper, while the presence or absence of livestock like goats, and the alignment of sacred boundaries with watershed contours rather than relative to human population centers are viable preliminary hypotheses. The difference among the sacralized terrains, however, points to the absence of comparative studies of the relative success of specific religious means for conservation in different cultural and ecosystemic contexts.

It is easy to view the difference between state and Native American management of salmon fisheries as a conflict between Christian anthropocentrism and nature-friendly animism. Christians certainly did engage in exploitive behaviors and policies. However, the post-colonial concept of rivers and ocean waters as common property that countered Pacific tribal division of salmon fisheries into watershed-based territories has deep legal roots in pre-Christian Roman jurisprudence that defined rivers and shores as res communis or areas open to all [16]. The importance of ship-based commerce and 
of maintaining free passage on navigable waters likely informed Roman bans on private ownership of the Tiber River. Just as res communis falls short when encountering diesel-powered trawlers or marine plastic debris, animist, polytheist and monotheist religious systems can fail environmentally or lack means to cope with today's environmental stresses. In-depth examination of how and when religious systems maintain or improve sustainability is far more useful than vaguely defined categories or stark dichotomies.

\subsection{Monotheism as a Foundation for Sustainability —Cases from Cultivation and Architecture}

Lacking deified or spirit-infused species and natural objects, monotheism superficially appears to be inherently narrow and excessively centralized in its approach to nature, while animism expresses the diversity within ecosystems. Yet monotheists have historically demonstrated great imagination in creating sustainable agricultural and gardening systems, designing livable cities, and leading modern nature preservation projects. This suggests that monotheism does not by itself inhibit development of eco-dimensionality. To take a well-documented example, some of the oldest continually functioning urban gardens in the world are of Islamic origin. Among the best known are the courtyards of the great mosques, formal gardens such as those at Alhambra in Spain, and gardens enclosed in household patios. Islamic landscape designers and architects originally borrowed and astutely combined the technologies and aesthetics of Roman water systems, Byzantine mosaics, and Persian parks, among other influences. In Islamic gardens, every feature celebrates Allah as the source of all human provision and beauty [17].

Infrastructure we would now deem "sustainable" characterized Islamic gardens from their inception. The medieval Courtyard of the Oranges in the Aljama Mosque of Cordoba, Spain, (now a Christian cathedral) originally collected water from the roofs as well as drawing water from an aquifer and storing it in cisterns. Rather than being sprayed across the patio surface, water still flows along small channels to the bases of individual trees, reducing wastage and evaporation [17]. Grounds keepers control its release through small, channel-specific gates; only the amount needed is applied. The shaded court is a remarkable urban green space, providing a locale to socialize and meditate prior to prayers. Today's tourists linger at the fountain, originally installed for ablutions, and wander casually among the orange, cypress and olive trees. Islamic architects and landscapers have become masters of the livable "outdoor room," and deploy shade, living greenery and flowing water to moderate the micro-climate for urban residential and public spaces. Often the aquatic features are constrained-a diminutive basin lined with colorful tiles or a tidy irrigation channel among the beds. Limiting unnecessary evaporation and spillage, they accentuate the universal and primal importance of water. Islamic household gardens comfortably support family gatherings and religious practice. In arid climates, patios provide a salubrious ambiance for an outdoor evening meal, a chat with friends, or rest from the heat of the day. A cool and fragrant niche is the ideal place to pray and read the Quran.

Islamic philosophical foundations encourage thoughtful integration of geometry, biota and human constructions with a heightened sense of universal order. Religious teachings imbed ethos in the enterprise. Garden designer Emma Clark concludes that beyond the individual components lies the "force that draws them all together into a satisfying and harmonious composition: the concept of unity, at-tawhid, the profound message of the Quran, which penetrates every aspect of a practicing Muslim's life" [18]. The sayings of the prophet Muhammad encourage the cultivation of edible species as a form of charity, not just to humans but to wildlife: "No Muslim who plants trees and from their fruits the human being or the beasts or birds eat, but that would be an act of charity on the Day of Resurrection" [19]. The miniature swaths of paradise attract a diversity of birds, whose songs add to the aural pleasures of splashing fountains. The Qur'an discourages waste; thus, the layouts are attentive to water conservation and to fruiting sequences. Islamic thought does not separate the aesthetic from the useful, so plantings for flowering or fragrance freely mix with those providing fresh vegetables and fruit for the kitchen. Islamic urban gardens display exceptional eco-dimensionality in terms of biotic diversity, spatial utilization, technologies mitigating harsh urban and climatic 
conditions, and provision for human social and physical wellness $[17,18]$. They reduce the "thingness" of living organisms, by viewing their existence as inseparable from the activity of the great creator God. Mosque and household gardens draw on this rich eco-dimensionality to forward religious practices, including daily prayer, ablutions, religious gatherings, and reading or reciting sacred texts. For Muslims, the unity of God or God's universal presence underlies exceptionally aesthetic or practical environmental conceptualizations.

Among Christians, monastic houses and counter-cultural sects have frequently proven to be hot-beds for sustainable life styles or values. These forms of religious community focus on ethics, and on God as especially active within their own social milieu. They also see themselves as witnesses, setting a good example either to their own denomination or to Christians in general. In some cases, such as medieval monasteries developing new methods of tillage, these tightly knit groups have spread innovative technologies, while in other cases, such as Amish resistance to the internal combustion engine, they have eschewed novel tools as disruptive, materialistic or threatening their communitarian fabric. Sarah McFarland Taylor's book, Green Sisters provides an entrée into the daily life, motivations, and decision making of contemporary Roman Catholic women committed to religious vocations [20].

Selecting one example among many, Trappist monks at New Mellery Abby, Iowa, have elected to address a widespread need among Roman Catholics for a caring, yet less expensive, means for burying the deceased. Average Americans find the costs of a commercial funeral prohibitive, and families may be forced to borrow money and incur long term debt. Christian monastics consider their labors to be integral to the fulfillment of their vocations or their call from God. God's love should infuse the work, its goals and its products. The Trappists hand-fashion caskets and urns intended to respect the dead and ease the pain of loss for their families and friends. Favoring the slower growing hardwoods, New Mellery has developed a sustainable management plan for its forest lands to ensure availability of cherry, walnut and oak trees over many decades. A monk blesses each casket and urn, which makes the receptacle for the remains less of a status symbol, and more an assurance the departed will join the holy in the afterlife. For the monks, each act, including nurturing tree seedlings, brings the light of Christ into the world [21]. Although advocates for strict sustainability might argue coffins take up too much space in the earth's increasingly developed land surface, the monks are honoring family wishes at a time of distress. The practical theology of work draws attention to the outcomes and ethos of each act comprising the service, expanding the eco-dimensionality to incorporate the forest biota and their reproductive cycles. The infusion of divine love reduces the thingness of wood planks and mounds of clay — and of the material remains of the deceased. "Cradle to grave" care for the trees is a mirror of God's activity in the well-lived Christian life.

Christian environmentalism operates on a variety of models, and its strengths often parallel the polity of the sect or denomination. My current employer, Baylor University, was the first institution in the Waco, Texas region to encourage its architects to generate blueprints worthy of LEED certification. LEED or Leadership in Energy and Environmental Design is a program developed by the US Green Building Council. Baylor's initial sustainable building venture was part of a project to establish a new seminary during a period of theological battling among Southern Baptists and within the regional Baptist conventions. The George W. Truett Seminary orients toward the ministry needs of individual congregations and missions and gives precedence to training pastors and service professionals rather than graduating cadres of academic theologians. Their namesake was active in raising support for Baptist hospitals, orphanages and schools in the Dallas region, during the early 20th century. Certified in 2009, Baylor's first LEED building with its imbedded chapel is symbolic synthesis of Baptist commitment to participation in local civic welfare, and the centrality of shared worship and preaching in Baptist life. The City of Waco Chamber of Commerce has since moved into a LEED certified headquarters with a green roof. Baylor has expended its LEED projects to renovations of academic buildings, the new business school and even to the Allison Practice Field, an indoor football facility that received a LEED sub-score of $5 / 5$ for innovation [22]. Other green initiatives include the hiring of a university sustainability coordinator, a recycling program at sports events, and contracts for 
wind generated electricity. A student run community garden provides fresh vegetables to supplement unused food salvaged from university dining halls for transfer to missions offering meals for the homeless and displaced families. The university garden organizers have joined with the Waco city government and other stakeholders to open a Saturday farmers' market downtown.

The inherent Evangelicalism of the university and Baptist emphasis on community service have prompted environmental action in spheres bridging church and state, and tying the institution to the city with its many social issues. The concept of civic ecology [23], in fact, synthesizes compatibly with Baptist social ethics. Civic ecology and Baptist ethics share foundations in volunteerism and community service. On the other hand, my recent study-CHURCHScape: Megachurches and the Iconography of the Environment-found that some Evangelical churches have conscientious programs for water and native vegetation conservation and for moderating urban micro-climate on their grounds, and others had allowed asphalt parking lots to rule. For some congregations, the importance of spreading the 'good news' and thereby increasing church membership had turned environmentally degrading impermeable surfaces into a badge of honor. The most sophisticated grounds plans, in contrast, often installed outdoor meditative spaces, such as prayer trails, or maintained community gardens or outdoor green spaces open to their neighborhood-thereby expressing their theology and ethos via vegetable beds and urban wetlands. Churches installed permeable parking, connected to public transportation or rented parking from nearby businesses closed on Sundays or at night. Several megachurches have commissioned sustainable building designs and George W. Truett's former congregation-Dallas First Baptist, Dallas, Texas-had earned a LEED certification for the major renovation of their facilities, completed in 2014 [24].

The above monotheistic sustainability cases concern three different traditions and a range of scales from international to a single monastic property, yet display common threads. A belief in the unity of God does not inherently constrain biotic or ecological eco-dimensionality in practice, and can be advantaged in promoting synthesis in complex designs. The idea that God has generated the world as an integrated whole where every element has meaning reduces "thingness" and stimulates the search for a balanced relationship between humans and other organisms. Monotheism accomplishes this via different means than religions such as the Tukano, which gives precedence to clans and weaves keystone species into ancestral lineages. For monotheists, technology and human designs are divine gifts to be used with care, not just for the benefit of other humans but for the welfare of animals and plants. Different denominations and sects are more likely to adopt sustainable practices and planning if they can relate them to their religiously based social ethos, and connect them to established religious practices, spaces or needs. Conversely, successful implementation of sustainable buildings or gardens as support for prayer, celebrations and even family socializing, stimulates further innovation and conceptual transfer into the civic and business realms. Faith-based projects have a better chance of becoming firmly established if they incorporate their own language or semiotics (symbolism), and this can extend to very particular traditions such as an historic Islamic preference for demonstrative geometric designs rooted in cosmology. Often a sustainable project begins when religionists confront a contemporary issue, such as the ethics of constructing a new building, and then searches for guidance via sacred texts or historical writings, rather than beginning with cosmology and seeking an application. Utilization of sustainable strategies in creating comfortable meditative spaces or simple, yet beautiful, funerary settings bridges the sacred with day to day needs. Working from pre-existing strengths in social ethos, like Baptist concern for local community welfare and Islamic teachings discouraging waste, reduces resistance to new ideas, and builds foundations for multi-phase and continuing programs. Table 1 summarizes the indicators of viable foundations for sustainability among the Abrahamic faiths. 
Table 1. Indicators of viable foundations for sustainability and robust ecodimensionality among the Abrahamic faiths.

\begin{tabular}{cl}
\hline 1. & $\begin{array}{l}\text { Dialog with sacred texts or historic writings and other sources of guidance to } \\
\text { enrich eco-dimensionality. }\end{array}$ \\
\hline 2. & Fluid integration with religious space, time, ritual and practice. \\
\hline 3. & Infusion of religious aesthetics [25]. \\
\hline 4. & Incorporation in religious education. \\
\hline 5. & Justification aligned with sectarian religious ethical priorities. \\
\hline 6. & $\begin{array}{l}\text { Utilization of language and symbols that relate environmental concerns to other } \\
\text { aspects of religious life, such as providing comfort to the bereaved. }\end{array}$ \\
\hline 7. & $\begin{array}{l}\text { Multi-faceted characterization of God and attention to God's love and care } \\
\text { relative to interaction with the world and the environment, or interpretation of } \\
\text { sustainable practices as compliant with divine purposes. }\end{array}$ \\
\hline 8. & Perception of sustainability as enhancing religious community and life together. \\
\hline
\end{tabular}

\subsection{Critiques and Religious Preferences}

A practical political question is whether external critique of Abrahamic faiths is beneficial or whether it can divert or disorient faith-based environmental focus? General philosophical accusations, such as a unified God is unecological, denigrate central principles and core beliefs and thereby religious self-identity. Although not always intentionally disrespectful, negative appraisals devalue the community at which they are aimed. This is not the best way to open a conversation if the purpose is sharing values or introducing new ideas. Academic judgments frequently idealize philosophical process, and ignore realistic limitations on improving environmental policies and programs. Dichotomous analysis dismisses potential strengths of the religions in question, and does not present positive environmental programs as models. Repeated intellectual battling can distract from the implementation of environmental innovations and inhibit opening dialogs with applied science.

In Baptized with the Soil: Christian Agrarians and the Crusade for Rural America, environmental historian Kevin M. Lowe documents the rise of Protestant agrarianism in the first half of the 20th century-and its ultimate decline and reappearance [26]. Presbyterians, Methodists and other mainline denominations developed a theology of land conservation, and advocated for the survival and welfare of family farmers, in face of rural change. Christian agrarians utilized the term "Christian stewardship" to describe a proper relationship to the land. Good stewards combated soil erosion via practices such as plowing on the counter and planting cover crops. They treated the land as holy, and concurred "the earth is the Lord's." Churches celebrated Soil Stewardship Week, and 4-H Sunday (4-H is an educational youth organization led by agricultural extension agents). Committed farmers in turn began a God's Acre project and planted crops or raised livestock and donated the proceeds of the sales to their local congregation [26]. With many sympathetic Christians among their ranks, the US Soil Conservation Service encouraged this form of community participation in federally led programs, and even published a booklet entitled The Lord's Land [26]. Applied science and religion were communicating very well with each other and acting in concert.

As Lowe concludes, by the 1960s changes in agricultural economics and in the goals of the Protestant denominations were diverting attention from these programs. Lowe proposes the environmental movement beginning in the 1960s contributed to the displacement of Christian agrarians by developing new vocabulary based in "sustainable" agriculture as an intentional counter-cultural contrast to conventional agriculture [26]. Critiques of religious foundations inhibited invocation of established Christian models for conservation and replaced them with postmodern rubrics. Norwegian philosopher and Deep Ecologist Arne Naess dismissed "stewardship" as anthropocentric when he wrote: "The arrogance of stewardship consists in the idea of [human] superiority which underlies the 
thought that we exist to watch over nature like a highly respected middleman between the Creator and Creation" [27]. Christians themselves doubted the stewardship model because the language did not originate in the cosmogenic narratives in Genesis or they found it materialistic. Retrospectively examining the accomplishments of the US soil conservation movement through the Great Depression and World War II, the agencies and farmers involved hardly resolved every difficulty with salinization of arid lands or cattle trampling creek banks. They did, however, greatly reduce surface soil erosion, dust storms, and gullying, and they restored hundreds of thousands of hectares of degraded fields, pastures and forests. Even if philosophically imperfect, "stewardship" has been, in practical terms, a notable improvement.

Aside from the question of whether philosophers are the best advisors for farmers, this case brings up the issue of how to determine if a religious approach, along with its language, symbols, rituals and community functions, is environmentally beneficial or not. Christian agrarians treat the planting of wind breaks and leaving strips of woodland along streams as righteous acts, fulfilling God's mandate to care for the earth. They have not viewed sustainability as in conflict with stewardship, but have synthesized the vocabulary of sustainability into their Biblical justifications for creation care. Using eco-dimensionality as a metric, the original Christian agrarians and their $21^{\text {st }}$ century counterparts, including the followers of Wendall Berry and organizations like the Christian Farmers Federation of Ontario, Canada, (CFFO) that take stances on specific environmental concerns, differ in their attitudes toward mechanization and high yield varieties [28]. They all, however, consider the range of their impacts on wildlife and biodiversity, demonstrate concern for the health of streams and lakes, and weigh the social worth of a farm's production beyond the profit margin. In my home region, Christian agrarians are active in developing permaculture, low cost technology, and local farmers markets, as well as greening urban food deserts. The language of stewardship is back in fashion with organizations like the CFFO, who are up-to-date on the scientific studies such as those documenting the impacts of agricultural run-off and fertilizers on Lake Erie. The CFFO, with its Neo-Calvinist foundations, accepts contemporary environmental science understands climate change will ultimately affect their own methods and productivity. A sense of ethical responsibility is combatting ecological short-sightedness and a focus on short-term profits.

\section{Discussion}

I was probably the first author to use the term "eco-theology" in a scholarly journal article, when I argued with US Secretary of Interior James Watt's public statements concerning Christianity and environmental values during the 1980s [29]. From my perspective, eco-theology is a continuing and critical foundation for Christian environmental engagement and communication. Yet, if all the Abrahamic faiths accomplish is a rational justification or apologetic for environmental care based in scared texts, the infusion of spiritual practice, polity and ministry that characterizes religiously-based sustainability and eco-dimensionality will not materialize and mature. Further, world religions such as Christianity, Buddhism and Islam have formal philosophies or theologies, while most indigenous or regional religions do not, making parallel examination of ecotheologies challenging at best. Comparing the fisheries sustainability cases with the examples of Islamic and Christian sustainability, multiple communalities are evident (Table 2). First, religions of diverse origins sacralize physical locales or anchor environmental management in a religious conceptualization of place. This incorporates the Protestant treatment of the earth and soil as holy. The sacred spaces integrate into daily life, such as the Islamic household or the Protestant farm; or the associated religious activity sacralizes the spaces around it. The religious systems overlap or connect the environmental imagery of myths and sacred narratives with rituals, sacred spaces, and the arts relative to natural resources and living organisms. This integration reinforces the importance of sustainable practices. All the religions investigated utilize aesthetics to draw attention to and generate respect for keystone species, ecosystemic processes and resource conservation. This ranges from chants, to carvings of salmon, to floral plantings, to hand-made coffins. 
Table 2. Shared features of well-developed eco-dimensionality among indigenous and monotheistic religions.

\begin{tabular}{cl}
\hline 1. & $\begin{array}{l}\text { Maintaining ecosystemic processes via sacralization of physical spaces and terrains, and natural } \\
\text { temporal cycles. }\end{array}$ \\
\hline 2. & Synthesizing environmental imagery from myth, ritual and other religious elements. \\
\hline 3. & Infusing religious aesthetics and semiotics into sustainable practices. \\
\hline 4. & Accentuating environmental value and reducing thingness and materialism via iconography. \\
\hline 5. & Facilitating religious praxis via sustainability. \\
\hline 6. & Bridging the human and non-human via religious belief. \\
\hline 8. & Conveying principles for ethical harvest and discouraging waste and greed via rules or teachings. \\
\hline
\end{tabular}

In addition, the religions approach the barriers to environmentally valuing the non-human by similar means. Religious interpretation reduces the "thingness" of materials, natural resources and living organisms and treats them as more than mere human possessions or physical objects. In general, religious interpretation elevates their status beyond that of "intrinsic value". Coyotes and salmon appear as sages, and blooming fruit trees announce the beauty and the love of God. Religiously-based sustainability often facilitates religious praxis such as prayer, worship or feasting and unites communities or families in sacred space and time. This improves integration of sustainability into community life. The religions either anthropomorphize non-human entities or portray God as continually active and invested in the life of the planet. Religion bridges the spiritual, human and non-human. Both indigenous and monotheistic religions convey rules or principles of shared harvest and use, and discourage greed and waste. This varies from soft methods, like the First Fish Ceremony or "earth ethics," to hard methods like taboos or the armed enforcement of fishing territories. The religions create multiple scenarios modeling right and wrong action. Often these distinctions are not imbedded in religious laws, but in guides to decision making and initiating action, such as Coyote tales and Biblical proverbs. While the means vary, religions enhance and expand eco-dimensionality by assembling biotic inventories, drawing attention to multiple ecosystemic functions, relating natural process to human sacred time, and forwarding sustainable technologies. (Table 2) Although not all these features may apply to a specific case of religiously motivated strategy for sustainability, several are likely to be components of the most effective and long-lasting endeavors.

While eco-theology remains an important means of communication within a faith or denomination, applying moral, aesthetic and scientific imagination to the development of religious eco-dimensionality offers a more accessible and culturally neutral bridge for conversations with scientists and policy makers due to its refined interface with critical environmental factors. In addition, eco-dimensionality does not invoke the language of a particular religion, nor does it assume a religion embraces formal theology. The Baptist LEED certifications and Trappist forests indicate that eco-dimensionality can evolve relatively quickly within a religious context, and can transfer and integrate strategies from external sources. Islamic gardens and Christian agrarian farms demonstrate the ability of monotheists to simultaneously sacralize biotic inventories and sustainable technologies. "Soft" outreach by scientists, architects and extension agents, some of whom are co-religionists reduces barriers to the religious semiotics and practices that characterize an entrenched faith-based ethos of sustainability. In all these cases, community networking was prominent, although the social scale at which it operated and whether it was predominantly inter-community or intra-community varied. The Islamic gardens and Baptist LEED certifications display willingness, even enthusiasm, for sustainable technology transfer at interregional scales.

The concept of eco-dimensionality can assist in determining why religions have difficulty tackling contemporary environmental challenges. The importance of the Sunday sermon in Christian ethical instruction, for instance, might appear to be an advantage in terms of teaching environmental ethics. 
As the cases demonstrate though, a sermon alone is detached from environmental space and time as well as from environmental action. Greening indoor and outdoor spaces, enhancing local ministries by adopting sustainable practices, holding an outdoor service, or sponsoring an environmental community service event all contribute to eco-dimensionality—and reinforce sermonic lessons. Hiring a LEED certified architect to direct a building renovation is a righteous or holy endeavor, that a congregation can celebrate from initiation to completion. For Christians, discriminating between the influence of concrete institutional sustainability programs and educational publications aimed at modifying consumer ethos in the personal sphere could improve the efficacy of both.

A last inference from the cases is that improperly generalizing the environmental ethos of a religious group like Christians, Muslims or Evangelicals can generate inaccurate assumptions about receptivity to scientific or policy approaches to sustainability. The degree to which the environment takes religious ethical priority is indeed quite differential, ranging from rarely discussed, to the high level of concern identified in the Papal encyclical letter Laudato Si: On Care for Our Common Home [30]. Among denominations and congregations, the specific hermeneutical approach to interpretation of sacred texts can present constraints. An oft identified barrier for Evangelicals, for instance, is a focus on apocalyptic events or the 'last days.' Frequently, however, what appears to be a religious preference also has political or economic roots. According to a 2014 American Academy of Religion survey, for example, a mere $27 \%$ of white Evangelical Protestants Americans are climate change "Believers." The same survey found, however, that party line mattered, with $65 \%$ of Democrats self-reporting as climate change "Believers" versus $22 \%$ of Republicans. They also found that Americans rarely hear climate discussed by clergy in church, suggesting strongly held opinions are formed elsewhere [31]. Other studies similarly conclude that US Christian responses to climate change correlate with socio-economic variables and political party affiliation [32-34]. While many American Evangelicals have resisted federal and state regulations and programs intended to mitigate release of greenhouse gases and thereby climate change, this is not true of all institutions or congregations that might be categorized as Evangelical. American Evangelicalism incorporates Reformed, Anabaptists, Baptists, Wesleyans and Pentecostals among its many denominational threads. Neo-Calvinist practicality and friendliness to climate and aquatic science (also true south of the Canadian border) and LEED certified Texas Baptist chapels suggest a nuanced framework with a range of economic and ethical priorities. Many of the institutions belonging to US-based Coalition of Christian Colleges and Universities, with its core of Evangelical denominational affiliations, offer environmental undergraduate majors and graduate degrees. Scientists and social scientists who self-identify as Evangelical, such as Katherine Hayhoe and her husband Andrew Farley, who pastors a church, have committed their careers to studying and mitigating climate change [35]. In approaching Evangelicals concerning climate science or sustainability it is therefore critical to first consider which Evangelicals are joining the conversation.

\section{Conclusions}

The concept of eco-dimensionality offers a means for comparing sustainable practices and ethos among religious traditions. Eco-dimensionality results from an evolutionary process of communally engaging in environmental problem solving. The components of religious eco-dimensionality incorporate: inventories of biota and ecosystemic processes, recognition of ecological and environmental spatial and temporal dynamics at multiple scales, understanding of communitarian and anti-communitarian human behaviors, structuring of social networks at multiple scales, inventories of and developmental platforms for sustainable technologies, and an integrative repertoire of religious symbols, aesthetic endeavors and practices. Eco-dimensionality can be lost or diminished, as was the case with legislative interference with Pacific salmon fisheries. It can also be evolved to address new issues, as in the case of LEED certified buildings, or it can be recovered or restored, as is the case in contemporary Christian agrarianism.

Acknowledgments: I thank the Department of Environmental Sciences, Baylor University, for funds supporting travel to professional meetings and other activities contributing to this publication. 
Conflicts of Interest: The author declares no conflict of interest, other than already identified affiliation with one of the religious institutions discussed in the article. The founding sponsors had no role in the design of the study; in the collection, analyses, or interpretation of data; in the writing of the manuscript, and in the decision to publish the results.

\section{References}

1. Taylor, B. Dark Green Religion: Nature Spirituality and the Planetary Future; University of California Press: Berkeley, CA, USA, 2009, ISBN 978-0520261006.

2. Pew Research Center for Religion in Public Life. The Future of World Religions: Population Growth Projections, 2010-2050; Pew-Templeton Global Religious Futures Project: Boston, MA, USA, 2015.

3. Stark, R. What Americans Really Believe; Baylor University Press: Waco, TX, USA, 2008, ISBN 978-1602581784.

4. Jenkins, P. The New Faces of Christianity: Believing in the Bible in the Global South; Oxford University Press: New York, NY, USA, 2008, ISBN 978-0195368512.

5. Bratton, S.P. Religion and the Environment; Book Manuscript in Preparation for Routledge Publishers: Abingdon, UK, 2018.

6. Taylor, J.E., III. Making Salmon: An. Environmental History of the Northwest. Fisheries Crisis; University of Washington Press: Seattle, WA, USA, 1999; pp. 1-72, ISBN 978-0295981147.

7. Judson, K.B. Coyote and the salmon. In Myths and Legends of the Pacific Northwest, Especially of Washington and Oregon; A.C. McClurg \& Co.: Chicago, IL, USA, 1910; pp. 123-124.

8. Swanton, J.R. Moldy-forehead. In Haida Texts and Myths; U.S. Bureau of Ethnography, Smithsonian Institution: Washington, DC, USA, 1905; pp. 7-13.

9. Chernela, J.M. Indigenous knowledge and Amazonian blackwaters of hunger. In Cultural and Spiritual Values of Biodiversity; Posey, I., Ed.; United Nations Environmental Program: London, UK, 1999; pp. 423-426.

10. LeVasseur, T.; Peterson, A. Religion and Ecological Crisis: The "Lynn White Thesis" at Fifty; Routledge Publishers: New York, NY, USA, 2017, ISBN 978-1138644120.

11. White, L., Jr. The historic roots of our ecological crisis. Science 1967, 155, 1203-1207. [CrossRef] [PubMed]

12. Thirgood, J.V. Man and the Mediterranean Forest: A History of Resource Depletion; Academic Press: New York, NY, USA, 1981, ISBN 978-0126872507.

13. Harrison, R.P. Forests: The Shadow of Civilization; University of Chicago Press: Chicago, IL, USA, 1992; pp. 52-58, ISBN 978-0226318073.

14. Breneman, W.L., Jr.; Brenneman, M.G. Crossing the Circle at the Holy Wells of Ireland; University of Virginia Press: Charlottesville, VA, USA, 1995, ISBN 978-0813915487.

15. Walsham, A. The Reformation of the Landscape: Religion, Identity, E Memory in Early Modern Britain E Ireland; Oxford University Press: Oxford, UK, 2011, ISBN 978-0199654383.

16. Brown, J.; Colling, A.; Park, D.; Phllips, J.; Rothery, D.; Wright, J. Case Studies in Oceanography and Marine Affairs; Pergamon Press: Oxford, UK, 1991; pp. 40-43, ISBN 978-8008093974.

17. Rogers, E.B. Landscape Design: A Cultural and Architectural History; Harry N. Abrams: New York, NY, USA, 2001; pp. 104-108, ISBN 978-081090924530.

18. Clark, E. The Art of the Islamic Garden; The Crowood Press: Marlborough, UK, 2010; p. 38. ISBN 978-1847972040.

19. Khan, A.K. Plants, Gardens and the Quran; Jasmina Press: Karachi, Pakistan, 2001.

20. Taylor, S.M. Green Sisters: A Spiritual Ecology; Harvard University Press: Cambridge, USA, 2009, ISBN 978-0674334952.

21. Trappist Caskets, New Mellery Abbey. Available online: Trappistcasket.com (accessed on 14 October 2016).

22. "Baylor" and "Truett Seminary" in Projects, US Green Building Council. Available online: Usgbc.org (accessed on 15 February 2018).

23. Krasny, M.E.; Tidball, K.G. Civic Ecology: Adaptation and Transformation from the Ground Up; MIT Press: Cambridge, MA, USA, 2015, ISBN 978-0262028653.

24. Bratton, S.P. CHURCHScape: Megachurches and the Iconography of the Environment; Baylor University Press: Waco, TX, USA, 2016, ISBN 978-1-4813-0383-5.

25. Bratton, S.P. Environmental Values in Christian Art; State University of New York Press: Albany, NY, USA, 2008, ISBN 978-0-7914-7265-1. 
26. Lowe, KM. Baptized with the Soil: Christian Agrarians and the Crusade for Rural America; Oxford University Press: New York, NY, USA, 2016; pp. 137-176, ISBN 978-01090249458.

27. Naess, A. Ecology, Community and Lifestyle: Outline of an Ecosophy; Cambridge University Press: New York, NY, USA, 1989; p. 187, ISBN 978-0521348737.

28. Christian Farmers Federation of Ontario. Available online: Christianfarmers.org (accessed on 28 August 2017).

29. Bratton, S.P. The Ecotheology of James Watt. Environ. Ethics 1983, 5, 28-40. [CrossRef]

30. Pope Francis, Bishop of Rome. Laudato Si: On Care for Our Common Home; The Vatican: Rome, Italy, 2015. Available online: https: / / laudatosi.com (accessed on 26 March 2018).

31. Cox, D.; Navarro-Rivera, J.; Jones, R.P. Believers, Sympathizers, and Skeptics: Why Americans Are Conflicted about Climate Change, Environmental Policy, and Science; Public Relations Research Institute: Washington, DC, USA, 2014.

32. Bratton, S.P. Tradition as benefit or barrier: The case of US Christian religion in the formation of environmental ethics. In Linking Ecology and Ethics for a Changing World: Values, Philosophy, and Action; Rozzi, R., Pickett, S.T.A., Palmer, C., Armesto, J.J., Callicott, J.B., Eds.; Springer Publishers: New York, NY, USA, 2014; pp. 71-84, ISBN 978-94-007-7469-8.

33. Carr, W.; Patterson, M.; Yung, L.; Spencer, D. The faithful skeptics: Evangelical religious beliefs and perceptions of climate change. J. Stud. Relig. Nat. Cult. 2012, 6, 276-299. [CrossRef]

34. Tampio, N. Green allies: Speculative realism, Evangelical Christianity, and political pluralism. Political Theol. 2016, 17, 525-539. [CrossRef]

35. Hayhoe, K.; Farley, A. A Climate for Change: Global Warming Facts for Faith Based Decisions; FaithWords Press: Nashville, TN, USA, 2011, ISBN 978-0446549578.

(C) 2018 by the author. Licensee MDPI, Basel, Switzerland. This article is an open access article distributed under the terms and conditions of the Creative Commons Attribution (CC BY) license (http://creativecommons.org/licenses/by/4.0/). 